\title{
Transatlantica
}

Revue d'études américaines. American Studies Journal

\section{"Magic Portraits Drawn by the Sun": New Orleans, Yellow Fever, and the sense(s) of death in Josh Russell's Yellow Jack}

\section{Owen Robinson}

\author{
(2) OpenEdition \\ Journals \\ Édition électronique \\ URL : http://journals.openedition.org/transatlantica/5393 \\ DOI : $10.4000 /$ transatlantica.5393 \\ ISSN : $1765-2766$ \\ Éditeur \\ AFEA
}

Référence électronique

Owen Robinson, " "Magic Portraits Drawn by the Sun": New Orleans, Yellow Fever, and the sense(s) of death in Josh Russell's Yellow Jack», Transatlantica [En ligne], 1 | 2011, mis en ligne le 03 janvier 2012, consulté le 29 avril 2021. URL : http://journals.openedition.org/transatlantica/5393 ; DOI : https:// doi.org/10.4000/transatlantica.5393

Ce document a été généré automatiquement le 29 avril 2021.

\section{(c) (1) $\odot$}

Transatlantica - Revue d'études américaines est mis à disposition selon les termes de la licence Creative Commons Attribution - Pas d'Utilisation Commerciale - Pas de Modification 4.0 International. 


\title{
"Magic Portraits Drawn by the Sun": New Orleans, Yellow Fever, and the sense(s) of death in Josh Russell's Yellow Jack
}

\author{
Owen Robinson
}

\section{Introduction}

1 Through the best and worst of times, New Orleans is a particularly sensory city. Its cuisine is as renowned as its music, its architectural beauty as intense as the heat and rain that beat down upon it. The horrors unleashed by Hurricane Katrina and her political partners-in-crime in 2005 and since have reminded the world of the city's fragility, as well as the particular circumstances of its geography and climate. Accompanying the terrible images of bloated corpses and thousands trapped in an apparently abandoned city were numerous descriptions of the awful sounds and smells of the disaster, the stench of death and neglect exacerbated by the intense heat and stagnating, polluted floodwaters. But this is far from the first New Orleanian disaster to manifest itself through the senses in this way. The series of yellow fever epidemics that devastated New Orleans through the nineteenth century were also the result, in part, of the city's geographical position, its unforgiving climate, and the policies of interested parties; the fever's awful death toll was likewise accompanied by a grotesque array of sights, sounds and smells. These horrors are chronicled and dramatised in many forms and in ways that display both various impressions of the significance of yellow fever itself, and of how it figures the city of New Orleans as a site in both the United States and in the wider Americas. There are too many examples to discuss in detail here, and rather than present a survey, as such, I am going to take as my main focus Josh Russell's 1999 novel Yellow Jack, after looking briefly at the narrative presence or absence of the disease in some contemporary accounts. My focus, therefore, will be on yellow fever, rather than Katrina, but I would like to allow some space for consideration of how the 
two forms of disaster inform each other and inform the city, its population, and the wider region(s).

2 Josh Russell, professor of creative writing at Georgia State University in Atlanta, is the author of two historical novels and several short stories set in New Orleans. His most recent book, My Bright Midnight (2010), charts the experiences of a German émigré to the city in the 1930s and '40s, which become ever more complex and troubled as the United States gets increasingly involved in the Second World War. My focus here, however, is on the story of another New Orleanian who has fled from Europe around a century earlier, in Russell's first novel, Yellow Jack (1999). This fine, under-acknowledged book at once offers a harrowing portrait of the yellow fever epidemics of the late 1830s and early 1840 s, and a study of the representations of the city and its peculiarly sensory disaster. The fictional protagonist, Claude Marchand, is a Paris wastrel taken under the wing of the early pioneer of photography, Louis Daguerre, the non-fictional selfprofessed inventor of the daguerrotype. Following a violent dispute over professional secrets being divulged to a prostitute and others of ill repute, Marchand steals his master's prototype camera and flees to New Orleans, where after an initial spell of squatting and street banditry he sets up business as a maker of portraits, and becomes entrenched in a web of erotic intrigue, drug addiction, and the city's sense of itself in the early-to-mid nineteenth century. The novel gives a steamy, torrid account of his overlapping relationships with Millicent, a mixed-race prostitute whom he meets at a creole ball and sets up home with, and Vivian Marmu, the daughter of one of his most prominent patrons, who is disturbingly (even to Marchand) young when they begin their relationship, and who eventually becomes his wife. Inextricably bound up with his complex personal life is his career as a photographer of the city and its inhabitants. At times both courted and scorned, Marchand's story brings us into contact with figures at every level of New Orleans society, from robbers and street urchins, to doctors and businessmen, to the mayor, before his own death several years after his arrival in the city, as foretold in the book's opening pages (we might say, indeed, that a "sense of death" pervades the novel from the outset, as we are always conscious of Marchand's demise). We are given a detailed, finely wrought depiction of the conditions of life in New Orleans in the decades after the Louisiana Purchase, and of the class, gender and racial codes that govern its people. Perhaps most vividly of all, Yellow Jack evokes the horror of the titular disease and the catastrophic toll it takes on New Orleans. Marchand's camera captures the haunting images of his own doomed life, and the fever-ravaged city living and dying around him. As Marchand makes "soliotype" memorial images of the dead, his perceptions and experiences are ever more influenced by the noxious chemicals he uses for his trade, and the opium that he smokes. Meanwhile the city is overwhelmed by the smoke from tar burnt in futile attempts to keep "Mister Jack" at bay, and the smells of death become ever more unbearable. As well as providing an intense fictional encounter with a formative period in New Orleans's history, Yellow Jack is a sophisticated study of the role of visual imagery in documenting such horrors, whose prose is steeped in the smells and sounds of the time and place. This article, then, will discuss this novel's intense engagement with the various "senses" of a very particular Southern place. 


\section{Talking and not talking about the "fever topic"}

3 Alongside cholera, smallpox, and other deadly diseases, yellow fever ravaged New Orleans throughout the late-eighteenth and the nineteenth centuries, much as it laid waste to countless sites throughout the Americas and further afield. The city's position in almost impossibly swampy terrain between the Mississippi in its final convoluted stages, and Lake Pontchartrain, in the wider context of the Gulf of Mexico and the Caribbean, rendered it extremely humid during the summer months, and essentially water-bound, notwithstanding its ostensibly inland site. Furthermore, its growing importance as a trading centre in the region, crucial to economic interests to both its north and its south, made it a major urban centre, as well as a place with significant transient, temporary population groups connected to the vessels that joined New Orleans to the wider world in ever-shifting terms. This combination of environmental, geographical, demographic and economic circumstances made it particularly vulnerable to the ravages of so-called "Yellow Jack," and ultimately the disease took the lives of over 40,000 New Orleanians, and 100,000 Louisianians overall (Campanella, $2008,26)$. The epidemics varied in frequency and ferocity, but major outbreaks blighted the city with terrifying force at numerous points throughout the nineteenth century. A single summer, that of 1853, saw almost ten per cent of New Orleans' population-that is, some ten thousand people-killed (Kelman, 87-9). As well as the sheer scale of the death tolls, and the agony of those who suffered, the symptoms were an horrific assault on the senses of those dying and those trying to live on in the sick city. Jaundice gave the disease its disarmingly colourful name, while what Ari Kelman has called "yellow fever's signature symptom" was black vomit caused by gastrointestinal hemorrhaging (Kelman, 2006, 90-1). Those spared by "Mister Jack" then had to live in a city illequipped, and at times insufficiently motivated, to deal with its consequences: woefully inadequate hospitals and morgues, overwhelmed graveyards and cemeteries, and the constant stench of death and disease. Appalling sanitary conditions, extreme heat, and stagnant water all contributed to the sensory horrors, and directly rendered the city more vulnerable to the disease itself by providing an ideal breeding ground for the mosquitoes which were only proved to be its carriers at the turn of the century (Campanella, 2008, 234).

4 Meanwhile, the city's leaders and advocates would frequently attempt to play down or even deny the presence of the disease, for fear of damaging trade, and the narrative presence-or absence-of yellow fever is a fascinating and grim tale in itself (Kelman, 2006, 94-99). During that particularly terrible summer of 1853, for instance, Bennet Dowler, in his "Geographical, Commercial, Geological, and Sanitary" Tableaux of New Orleans argued strenuously against threatened quarantine regulations that could stifle economic prospects. He expounds colourfully on the reasons why "[t]he climate, geographical position and natural advantages of New Orleans, are guaranties of what she ought to be, and will be" (Dowler, 1853,3), and like other advocates of the city's potential greatness, does not hold back with the historical examples it would purportedly supersede should free-market capitalism be allowed to flourish unimpeded:

A city, to become permanently great, ought not only to be situated in a genial

climate, but it ought to have the sea before it, gemmed with islands like Cuba and other West Indian Islands, and a thousand armed river behind it, reaching through a vast extent of latitude and longitude. It ought also to be situated in an alluvial 
plain, exuberant with food and the raw materials for raiment. Babylon flourished on the alluvial plain of the Euphrates; Nivenah on the Tigris; Thebes, Memphis, and twenty-thousand cities and towns, on the Nile-rivers and plains incomparably inferior to the river and valley on which New Orleans stands...(6)

Dowler is as strenuous in his denial of the dangers of the city's position and conditions as he is in his promotion of their commercial advantages, suggesting that "[ $t]$ here is not, probably, any considerable city in North or in South America, including the West Indies, whose sanitary history is so favorable as that of New Orleans, until near the close of the last century," before proclaiming from on high that "this author asserts that from the end of October to the beginning of June, there is in both town and country but little sickness, and that death but rarely occurs" (23). Even as it conveniently avoids those summer months in which sickness and death demonstrably occurred on a huge scale, this is a strikingly cavalier statement to be made in this of all years.

6 As Ari Kelman discusses, such fears on the part of New Orleans political, commercial and journalistic elites were not without foundation on their own terms, as trade inevitably suffered greatly during epidemics: business stayed away, and thousands of the city's workers perished (Kelman, 2006, 94). Visiting writers, or those less immediately concerned with finances, unsurprisingly often took a somewhat different view on the ethics of the narrative of yellow fever, however. An important figure from the early-nineteenth century, the architect and engineer Benjamin Latrobe, gives a forceful account of the dialogue between official and commercial narratives on the one hand, and word on the street on the other, following the arrival in July 1819 of a stricken ship from "the Havanna" and the deaths of two of its sailors in New Orleans itself:

From that time rumors of yellow fever cases became daily more frequent, \& by the beginning of August it was a matter of notoriety that the disease did exist. Every notice, however, of the calamity was carefully kept out of the newspapers. I asked one of the editors from what motive this omission arose; his answer was, that the principal profit of a newspaper arising from advertisements, the merchants, their principal customers, had absolutely forbid the least notice of fever, under a threat that their custom should otherwise be withdrawn; thus sacrificing to commercial policy the lives of all those who, believing from the silence of the public papers that no danger existed, might come to the city (Latrobe, 1951, 146).

7 Having pertinently noted the relationship between commercial self-interest, public silence, and the fact that in this case rumour was more accurate than the official line, Latrobe himself fell victim to yellow fever and died the following year. It is also worth noting that, effectively and fatally silent though the New Orleans press may have tended to be during outbreaks, "newspapers in rival Northern ports, particularly New York, document[ed] New Orleans' yellow fever miseries enthusiastically" (Campanella, $2008,35)$. Alert to the dangers, Latrobe himself cannot count as one of the "sacrificed" that he describes, but nonetheless his account of this situation and his exchange with the newspaper editor is chilling, and indicative of what was to come periodically on an even greater level as the century wore on, both in terms of the disease itself, and of the ways in which New Orleanians talked, or didn't talk, about it-narrative relations that Josh Russell dramatises in Yellow Jack.

8 Of particular interest for my purposes in this article is the point that these travelling commentators would frequently discuss yellow fever in the city in terms that appeal to, or perhaps appal, the senses. Thomas K. Wharton, an Englishman long resident in the 
United States when he came to New Orleans in the 1850s, offers impassioned accounts in his journal of the progress of the disease as he encounters and hears of it in the city, as well as reporting disturbing new rumours of its resurgence in key trading sites such as Havana, noting that the fever "has raged so long in Cuba that with our total disregard of Quarantine regulations it would be next to a miracle if we escaped it" (Wharton, 1999, 41). Wharton often laces his descriptions with vividly sensory evocations: his entry for September 27, 1854, for instance, reads "Every thing damp, clammy and blighted with mold \& mildew. No wonder the epidemic conditions so bad" (47). He bemoans the lack of wind: there is, he says

[n]o motion to carry off the gases of a populous, damp and almost tropical city. Still the general health has been good, and the West India plague, yellow fever, or whatever it may be named has been kept out-by Quarantine. This, rigidly enforced, would save New Orleans a world of sorrow, yet there are hundreds so infatuated as still to deny its efficiency ( 145 , underlining in original).

These points, along with broadsides against the irresponsible denials of figures like Dowler, and the recklessness of the "strangers who persist in rushing to the city in quest of situations, which is simply suicide" (179, underlining in original), cumulatively amount to a powerful rebuttal of the more "official" line, not least through providing ample narrative of the physicality of the devastation as clearly evidenced in the city's streets and houses.

10 The visiting "Manhattaner," A. Oakey Hall, writing in 1851, noted that New Orleanians of all stripes regarded the fever with varying degrees of attention according to the time of year, or stage in the economic cycle:

Throughout the winter in New Orleans the "fever topic" rather drags in conversational circles. To the "old inhabitants" it is an old story; to the unacclimated it is like allusions to that first promissory note due six months hence which figures on the books of a young tradesman. But when cloaks and thick coats disappear, and pedestrians contemptuously kick about the stray lumps of coal occasionally met with; and the suns of latter May crisp the tops of new carriages, discussions upon the fever are agitated (Hall, 1851, 66).

11 The mixture of complacency and economic self-interest during the disease's fallow periods is described in lively terms by Hall here, and he perhaps disingenuously emphasises that he is writing for a "literary world" which he does not wish to "bore" with medical or sociological details, notwithstanding his having suffered and survived the fever himself (65). This said, his notes from experience on "how one feels under an attack of yellow fever" are vivid: after perhaps disingenuously suggesting that anyone who has had a hangover will have some idea of it, he tells us that

A civil war is raging in the stomach, while the temples and the pulse beat a tatoo [sic] for the engagement. The head feels as if filled with molten lead which is burning the eyeballs. The back is like an unhinged door. You seem infatuated with a desire to immortalize yourself by a discovery of perpetual motion, and influenced thereby toss from side to side like a rudderless vessel off the banks of Newfoundland. Daylight becomes a nuisance. The most fascinating of tongues loses its eloquence (69).

These accounts and many others provide awful testimony to the public and private lives of "Mister Jack" in New Orleans. Having in effect been given free reign by the selfinterested silence or denials of official or commercial narratives, the journals of residents and travellers, as well as the compelling suggestion of rumor and other subversive accounts, work hard to expose his malign presence. These richly Bahktinian 
dialogues of denial and exposure, of the undermining of official silence by popular voice, of the physical and psychological horrors of the disease and its broader effects on the community, and of New Orleans' place in the wider region, are major concerns of Russell's Yellow Jack. As the doctor Victor Benton puts it to his friend, the protagonist Marchand, "No city can be free of Yellow Fever while quarantines are bought and sold, animals are left rotting where they die, and people are not stopped from dumping their shit into the streets" (Russell, 1999, 211). Russell adds a particularly intriguing ingredient to the mix, however: photography, and the connotations it has for the relationships between art, truth, life, the senses, and human motivation.

\section{The interpenetration of the senses in Yellow Jack}

13 Yellow Jack is a complex novel, somewhat Faulknerian in its weaving of the narratives of a late-twentieth-century art historian, the diary entries of Marchand's octoroon wife/ lover Millicent, and, most prominently, the detailed but unreliable and in some ways impossible narrative of Claude Marchand himself. These narratives unknowingly inform and contradict each other, at times telling quite different versions of the same events, but they are linked in their dependence on, indeed obsession with, sensory effects. Movement, thought, action are described in rich, sensory terms throughout. For instance, soon after his arrival in the city, Marchand wanders the streets, listening to the cathedral's bells chiming:

Just after they sounded four o'clock I followed my nose down an alley and found a baker stacking fragrant wands of bread into his cart. Swooning from the brown smell I begged him for a batard and he spat at me. I produced the pistol with which I had intended to murder Daguerre. I felt no guilt, the weapon was harmless: I'd fired its only ball at an angel who stuck out her tongue at me [in a vision]. The baker cried out as if shot, then fainted. I took as many loaves as I could carry. Hidden in my tobacco shop, I gorged on bread, the cannons giving cadence to my chewing, and the sun rose dully behind black clouds (Russell, 1999, 20).

This is an example of the novel's intertwining of its characters' sensory pursuits (here the pursuit of food) with the continual mixing of sensory effects in their description. Emphasis is placed on Marchand's being led by his sense of smell before "swooning from the brown smell," but sound and vision become as imperative as the imagined shooting is vocalised by the baker, and the fever-fighting cannons (about which more later) and grim sunrise inform his frenzied eating. Indeed, it seems at times as though every sentence evokes or appeals to the senses, and part of the novel's narrative opulence, and the decadent, ragged glory of the city it describes, comes from the heady precision of these images and mixture of senses that they appeal to: "Louisiana sunlight," Marchand tells us, for instance, "is heavy and golden and warm, like Armagnac" (51). Atmosphere and mood are frequently described in terms that gain much from gradual, skilful accumulation. When we are told, around a third of the way through the novel, that "the air smelled of a coming storm," we can divine by this stage that this refers both to the vigilante suppression of a rumoured slave rebellion in the city, and the similarly threatful weather (77). Personal appearance, sometimes racial, is likewise described with minute sensitivity to colour: a love rival's eyes are described as "beady and the color of shit" (106); Millicent's skin has "a hint of purple"; the stark image, in an opium den, of "a woman so dark her edges lacked definition fellat[ing] a man white as chalk, his prick flashing and disappearing as she nodded" (80). 
15 All this, and many other examples, would be rich enough were it simply a means of description. However, the world in which Yellow Jack plays out is itself a confusion of the senses, the layered, sensual language evoking a time and place in which sight merges potently with sound and with smell and with taste and with touch. This both illuminates the portrayal of mid-nineteenth-century New Orleans itself-a wildly hedonistic cauldron of sex, drugs, food, death, and early photography in this tellingand infuses the key concerns of the relationship between art and life, the slippage between historical narrative and personal account, and, not least, the sheer horror unleashed by "Mister Jack" on a city already always in a state of transition. Marchand's arrival in New Orleans is figured as a brutal assault on the senses. Already suffering from having "vomited my weight several times over" on the Atlantic crossing, he describes his approach as even grimmer: "We took in supplies and cargo in Haiti, then crossed the Gulf of Mexico and aimed up the Mississippi. I became ill in a new waydrenching sweats, black vomit, visions even more vivid than those I'd experienced on the open sea" (18-9). At the docks he avoids being embroiled in a tax and tariff dispute involving bananas, and finds himself in a kind of hell:

I counted the bells ring ten times. Stinking smoke cocooned the lamps and I wondered if I'd died and gone to the Hell my father promised. When I finally met another man on the street he was masked. For a moment I was sure he was a bandit, but he crossed the narrow avenue to avoid me. I was watching his back fade into the fog when the cannons began to boom, rattling the boards covering the windows of the shop I stood before. The masks and guns and fire made sudden sense-it was July and I had arrived during America's violent celebration of independence (19).

16 As the firing of cannons, burning of barrels of tar and wearing of masks continues into August, Marchand comes to realise that they are "not props from an independence celebration but futile attempts at fighting the fever that'd rattled in my chest and come forth as coughs of inky syrup" (21-2). Marchand is arriving during a perceived carnival of sorts, a death hilarious whose mixture of terror and inadvertent celebration offers a sinister take on this New Orleanian standard. This is here much inflected by the yellow fever that the black vomit suggests Claude himself has arrived with, which presumably inoculates him against it in the contagious years to come. The hellish confusion of the scene, confused further by Marchand's mania, is registered in a potent mixture of sensory images, setting up a model for further such episodes to come. Though Claude survives Yellow Jack himself, his accounts of its ravaging of the city are increasingly heightened by his use of opium and his inhalation of the mercury he uses to develop his daguerreotypes (which he calls "soliotypes"). On one such occasion, just after an intense and disturbing sexual encounter with the fifteen-year-old Vivian Marmu, Marchand tells us that

The opium took quick effect and pictures began to flash behind my eyelids-Vivian with her bloody stocking clamped between her thighs, Millicent with her face buried in the pillows. I shook my head and heard my eyes rattle in their sockets. Smoke curled from pipes in gauzy question marks and my mind added questions before them (80).

17 Again, sight and sound, and real and imagined horrors, become muddled, as Marchand finds himself in a Saint Louis Cemetery Number 1 so overwhelmed with new inhabitants that the priests toss handfuls of dirt from their pockets onto the coffins, having "no time to bend and fetch." As he overhears a couple in the dark agonise over the burial of their young son, Marchand tells us that "a rope of smoke hung like a ghost above each flambeau. Black columns flecked with orange embers rose from burning tar 
barrels and brindled the sky. I felt fingers closing around my throat and ran from the graveyard" (81). This confluence of opium smoke and the oppressive thick black smoke from the tar continually burned by the city in the mistaken belief that it would ward off the fever occurs again and again, the garish "orange plumes" of the tar barrels setting off associated reveries of smell and touch. Marchand suggests that the plumes from the barrels are the smoking pipes of giants, as though New Orleans is intoxicating itself into a reckless denial of death even as its inhabitants die in their hundreds and thousands $(24,28)$.

And in some senses, of course, it is. New Orleans' pleasures are overwhelmingly sensory, and there is a feeling in the early stages of the novel that those braving the city despite the fearsome summer and the fever are playing games that indulge in the immediately satisfying rewards of life: the crowd at a ball in 1838 "were a jolly gang; an epidemic was not enough to make them sad," and it is here that Claude meets "a naked girl [...] supine across the table, covered with meats and fruit" (25). This is Millicent, with whom Marchand will have much food-infused sex during the course of their turbulent, complex relationship, often described in terms that require at least two senses for full effect, boldness of colour matching extremity of taste here, for instance: "I slid a sliver of golden papaya flash across her ribs, followed its trail with my tongue into her sharp armpit" (55). Food and drink are everywhere in this novel, tastes and smells at times defining the journeys or rendezvous of characters: Marchand pursues a gossip columnist on café trails, occasionally ending at a plateful of oysters; people constantly make, buy, or eat cakes; Millicent's balcony is so invaded by the chocolate and butter smells from a nearby pastry shop that "my cheese began to taste like a sweet" (117). Russell allows images to repeat and build a cumulative effect: the orange plumes and black smoke, and Millicent's touch of purple, for instance, but also this cornucopia of smells and tastes that suffuses everything. This creates a narrative plenitude and density that does much to provide the claustrophobic, trapped atmosphere of the novel, and gives a sense of great detail even though, in truth, the narrative rattles along at a fair speed. Perhaps the most explicit linking of illicit sex and rich food smells involves coffee. At one stage, Marchand rents a room above a coffee importer's warehouse for he and Vivian to use, in "the district fronting the docks" already heady with the sights, sounds and smells of a place full of cotton, sugar cane and bananas being unloaded, and the comings and goings of "whores and drunken sailors":

The smell of roasting coffee beans was overwhelming. It saturated the bed linen, the bread we brought to eat, the wine we drank, our clothes [...]. Once I brought a book home from the room. Sitting with Millicent the next day I opened it and the smell of coffee rose from its pages. I pulled Millicent from her chair and onto the floor. "What on earth were you reading?" she said as we lay panting among knotted shirts and torn skirts (98-9).

19 It could almost be the book we are reading, so suffused is it with these same smells, not to mention the sexuality that so closely accompanies it. Marchand does not tell us if his sudden ardour is inspired by uncontrollable urges triggered by the smell of coffee, or a more prosaic need to avoid interrogation on the unexpectedly pungent pages; either way, sex, scent, and food are evidently inextricable. 


\section{Sight, the "soliotype," and the art of death}

20 Above all else, however, sight, the visual, and visual art is at the centre of this novel's sensory overload. Claude Marchand is, after all, a self-styled pioneer of "the marvel" his original master Louis Daguerre "named [...] like an explorer would an islanddaguerreotype," but which Claude insists on calling "soliotype" (17). Having fallen out with Daguerre, the assistant Marchand, who in his telling is fundamental in the development of the process, vandalises his studio and flees to New Orleans with one of their prototype cameras. He begins exploiting this mysterious art in various ways almost as soon as he arrives, before, indeed, Daguerre has made his famous "announcement" of his discovery in Paris. From the beginning, the soliotype's status as "art" is discussed by Marchand and his associates, by his customers, by the newspapers, and by the latter day art historian whose exhibition commentary serves as fascinating counterpoint to Marchand and Millicent's narratives. It is Millicent who coins his original advertising slogan "Magic Portraits Drawn by the Sun," and who dismisses Claude's objection that it is in fact science that makes this art wonderful with the commercial point that "Telling someone there is no magic is a quick route to poverty" (40). Millicent herself is, at least at first, in thrall to the "magic" of the soliotype. Looking at the nude portrait Marchand has made of her, she muses "It is two mirrors at once [...].Tilt it one way and you see the past, tilt it another and you see the present" (26). The miniature-painter Peter is in no doubt as to the potentially dangerous importance of the process, saying "This soliotype of yours provides a perfect representation of Nature [...]. There are those who believe such perfection is an insult to God" (27). Peter himself serves as a literal example of the portrait painter transplanted by the photographer, as he is kicked out of the house-and the narrativeby Millicent, in favour of Claude. The unidentified author of the "guide" to a collection of Marchand soliotypes considers him one of the great neglected masters of photography, and this series of commentaries both seeks to reinstate his artistic reputation and to piece together his life from the scant resources available. Indeed, the slippages between what the art historian knows, or, more often, does not know, and what we come to know through our voyeuristic access to Claude's and Millicent's narratives is another of the novel's major concerns: to what extent can the historian, or indeed any constructor of an historical narrative (including the critic, and indeed the novelist, by implication), give us anything like a lived life? From the beginning, Marchand's "art" is the subject of multiple, clashing voices regarding its status, its motivations, and its effects.

21 At first, Marchand enjoys the success inspired by the sheer novelty of the soliotype, as New Orleanian socialites forsake traditional painting for his "magic sun portraits." As soon as his now rival Daguerre makes his announcement in Paris, however, the technology, at least, of this early form of photography is available to everyone, and numerous less skilled rivals spring up in New Orleans. In the early days, in the late-1830s, for his "official" work Marchand is more or less content to make people's portraits, and while he is diligent in his labours, not to mention contemptuous of his sitters' pretensions, this is for the most part a commercial exercise. Indeed, as he feels that "art is not realistic history" it doesn't even occur to him to make "views" of the city until his friend, the doctor Victor Benton, asks him to make some in order to "convince [his fiancée] Susanna that New Orleans is as much a city as Boston-there's a 
challenge worthy of your goal to build a high wall between art and reality" (121-2). The "guide" nonetheless gives great credit to these early works, as it does the two nudes in the forest that are praised by the guide for their formal skill; Marchand, however, has been more concerned with his encounters with the women in question: one he has sex with on the spot, while the other is the ten-year-old Vivian Marmu, with whom he becomes obsessed, to say the least. It would be a mistake to suggest that Marchand is unconcerned with artistic integrity, or a legacy, but his attitude towards his work-and in particular to that work which others, both contemporary and much later, often consider to be his most innovative and important-is frequently at odds with the integrity and legacy he is purported to have. There are two many fine examples of this to go through here, so I shall discuss just a couple, that in particular pose questions about the role of the photographer, or the artist more generally, and the particular limitations and possibilities of the daguerrotype/soliotype process-and particularly as they relate to death and its representation.

An image which the guide calls "Spirit Portrait of Charlotte Marmu Standing Behind Her Daughter Vivian, 1845" is lauded as showing "how a master like Marchand could transform one of the daguerreotype's shortcomings into a wonderful effect" (179). This shortcoming is the singularity of each daguerreotype, and the need for subjects to remain still while the exposure is still elapsing: there is no "negative" from which copies can be made, the unique image being created by the exposure to light of chemicals on the plate which is itself then the final and only product. Because of the time needed for the image to form on the plate, any movement on the part of the subject will produce a blurred image. Marchand is apparently exploiting this rather clumsy facet of the process to produce the ghostly effect described-made all the more spooky as the mourning Mrs Marmu herself died only a few days after the image was produced. As the guide would have it, Marchand brilliantly captures the fragility of life in the sick city, depicting Mrs Marmu moving between worlds. A few pages later, however, Claude himself describes his irritation as when he "was sure she'd made all needed adjustments, [...] when I removed the lens cover Charlotte Marmu briskly stepped from the portrait's frame", leading to a "botched" picture (186). His irritation at having to take another, "perfect" picture is then trumped by Mrs Marmu forcing her daughter to promise never to marry him, so it is probably safe to say that pushing the boundaries of the visual arts is not foremost in Marchand's mind as he produces this feted image. The guide is similarly impressed with a series of pictures that Marchand produces to document the chopping down of trees thought to harbour yellow fever, again exploiting the inadequacies of the daguerreotype to show the full descent of thirteen trees at once. Marchand himself, however, is again fatalistic about shots he knows will be "ruined" by the motion of the trees, and takes them only because he is being paid to (225-6). Marchand and Victor Benton argue about the worth of such images: Victor thinks them beautiful, as “The movement doesn't ruin it. Quite the opposite, I think. The motion you've recorded goes on forever in the mind of whoever looks at the trees falling," but Claude continues to insist that "The soliotype is a success only when a moment is preserved in a motionless frame" (227). Victor, one might posit, is arguably more visionary as regards Marchand's art than the artist himself-indeed, some of the techniques, indeed even some of the shots themselves, that the guide attributes to Marchand are actually at the instigation, and occasionally even the hand, of Victor Benton. 
More than anything else, Marchand's camera, and indeed the concentration of Marchand himself, are trained upon the awful ravages of the dreaded Yellow Jack, and the rumors, misapprehensions, and catastrophic denials of epidemic by city authorities, business leaders, and the press: "Some claimed hundreds were dying every day, their bodies burned at night by the mayor's henchmen to hide the epidemic. Others claimed only immigrants, poor and dirty, were susceptible. Twice-a-day bathing became a fad; stevedores and chimney sweeps were sweet with perfumed soap" (72). Susan Sontag, in On Photography, suggests that:

In fact, photography first comes into its own as an extension of the eye of the middle-class flâneur, whose sensibility was so accurately charted by Baudelaire. The photographer is an armed version of the solitary walker reconnoitering, stalking, cruising the urban inferno, the voyeuristic stroller who discovers the city as a landscape of voluptuous extremes [...].The flâneur is not attracted to the city's official realities but to its dark seamy corners, its neglected populations-an unofficial reality behind the façade of bourgeois life that the photographer "apprehends," as a detective apprehends a criminal (Sontag, 1977, 55-6).

Very much the armed flâneur that Sontag describes, Marchand walks the streets of New Orleans, "French" and "American" quarters alike, taking pictures of yellow placards on the doors of infected houses, men unloading barrels of tar and loading cannons, stonecutters working on gravestones, the bloated carcasses of rats and dogs left rotting in the streets whose stench is almost too much for Marchand to bear (Russell, 1999, 152-3). What he documents, again at least partly at the instigation of Victor Benton, is very much the "unofficial reality" that the city authorities and some quarters of the press want to cover up. "Photographs furnish evidence," says Sontag. "Something we hear about, but doubt, seems proven when we're shown a photograph of it [...]. A photograph passes for incontrovertible proof that something exists, or did exist, which is like what's in the picture" (Sontag, 1977, 5). Marchand's images stand in direct contradiction to the lies of the city leaders and their apologists, and indeed Benton mounts an exhibition with the goal of showing the true situation in all its horror. In ways perhaps reminiscent of the images of flooded lots filled with school buses that could have been used to transport people out of harm's way in 2005, these pictures of Marchand's implicitly expose the corruption, self interest and/or incompetence that is surely at least as responsible for the terrible death toll, through actively encouraging people to come to and stay in New Orleans, as the atrocious sanitary conditions and ignorance that allow the disease to fester and spread so virulently. And insofar as "all photographs are memento mori [...whose taking] is to participate in another's person's (or thing's) mortality, vulnerability, mutability" (Sontag, 1977, 15), the pictures also serve as grim tribute to the dead and the dying, whether or not this was actually intended by Marchand himself.

Meanwhile, "the dead queued up like nightmare devils and waited for their turn at me" (Russell, 1999, 153-4). In his own time, Marchand becomes most known as a maker of "memorial portraits," pictures of the recently deceased brought along by grieving relatives and posed in lifelike images that may seem in outrageously bad taste to us, but were considered a legitimate means of mourning in this time and place, as the "guide" tells us (71). Sontag notes that "the ethical content of photographs is fragile" (Sontag, 1977, 21), and Marchand himself fluctuates on the moral validity of these pictures (or perhaps his ability to keep taking them), at one stage refusing to take them anymore 
before essentially being forced to start again or go out of business: though Mister Jack may be bad for the city's commerce generally, he brings boom time for the memorialist. After a time, Marchand is "numbed by the sheer number of dead I helped pose for the camera. [...] New Orleanians were just as numb as I. They looked at portraits of relations living and dead with the same emotion" (Russell, 1999, 73). This never-ending parade of grotesques that Marchand must photograph makes for painful, hard-hitting reading, the musings on artistic responsibility and sensibility, and the complexities of commercial considerations that are intrinsically linked to these whether we like it or not, among the most anguished in the novel.

In 1831, the visiting traveller Henry Tudor reckoned that he had arrived at "the headquarters of Death" as soon as he disembarked in New Orleans (Kelman, 2006, 91). The rank smells, awful sights, terrible sounds and even horribly tangible tastes of mass death, and the heartbreaking effects on those left behind, are what ultimately linger most from reading this rather devastating novel. It does, of course, portray a particular time and place, and yellow fever is thankfully long gone from New Orleans. But the horror of awful death and appalling political and economic betrayal on such a mass scale is, of course, not a preserve of the nineteenth century either. Published in 1999, Yellow Jack obviously does not refer to Katrina, but reading it now, it is hard not to relate some of its scenes to those we know or may even have experienced from 2005 and after. Its concerns with the relationships between art and life, life and death, death and art, are universal, perhaps made all the more so because most readers see, hear, smell, feel and taste, and Russell excels in exploiting this in bringing the horror home to us. Lest we feel too glum, though, we also tend to eat, drink, have sex and make merry, and the book's exuberant portrayal of these crucial facets of New Orleans, then and now, is almost as marked, so there is, in typically New Orleanian fashion, plenty of relief to be found within the squalor.

\section{BIBLIOGRAPHIE}

BAKHTIN, Mikhail, The Dialogic Imagination: Four Essays, Michael Holquist, ed., trans. Caryl Emerson \& Michael Holquist, Austin, University of Texas Press, 1981.

BIBLER, Michael P., “Always the Tragic Jezebel," Southern Cultures vol. 14, University of North Carolina, 6-27.

CAMPANELLA, Richard, Bienville's Dilemma: A Historical Geography of New Orleans, Lafayette, Center for Louisiana Studies at the University of Louisiana, 2008.

DOWLER, Bennet, M.D., Tableaux of New Orleans, New Orleans, Daily Delta Office, 1853.

HALL, A. Oakey, The Manhattaner in New Orleans; or, Phases of 'Crescent City' Life, New York, J. S. Redfeild, and New Orleans, J. C. Morgan, 1851.

KELMAN, Ari, A River and Its City: The Nature of Landscape in New Orleans, Berkeley, University of California Press, 2006. 
LATROBE, Benjamin Henry Boneval, Impressions Respecting New Orleans: Diary \& Sketches, 1818-1820, Samuel Wilson Jr., ed., New York, Columbia University Press, 1951.

MACKAY, Alex, The Western World; or, Travels in the United States in 1846-47: Exhibiting Them in their Latest Development Social, Political, and Industrial; Including a Chapter on California. With a New Map of the United States, Showing their Recent Acquisitions, and a Map of California, vol. 2, London, Richard Bentley, 1849.

NEIHART, Ben, “Russell's 'Jack'-Powerfully Fragile," Baltimore Sun, August 15, 1999, http:// articles.baltimoresun.com/1999-08-15/entertainment/9908170404_1_josh-russell-new-orleansyellow-jack (last accessed on November $18^{\text {th }}, 2011$ ).

RUSSELL, Josh, Yellow Jack, New York, Norton, 1999.

SONTAG, Susan, On Photography, London, Allen Lane, 1977.

WHARTON, Thomas K., Queen of the South: New Orleans, 1853-1862, the Journal of Thomas K. Wharton, Samuel Wilson, Jr., Patricia Brady \& Lynn D. Adams, eds., New Orleans, Historic New Orleans Collection, 1999.

WINTER, Max, review in Time Out New York, quoted on flyleaf of Russell, 1999.

WOODS, Larry D., review in Nashville Tennessean, quoted on flyleaf of Russell, 1999.

\section{RÉSUMÉS}

Dans un certain sens comparables à la tragédie et aux conséquences de l'ouragan Katrina en 2005, les séries d'épidémies de fièvre jaune qui dévastèrent La Nouvelle-Orléans au cours du XIXe siècle furent aussi - du moins partiellement - le résultat de la situation géographique de la ville, de son climat insupportable et de la politique des milieux intéressés; de manière semblable, la rage de cette fièvre ravageuse était accompagnée d'un ensemble grotesque d'images, de bruits et d'odeurs. Dans cet essai, je me limite au roman Yellow Jack de Josh Russell, qui, publié en 1999, trace le portrait complexe de cette ville du milieu du xixe siècle, de ses épidémies de fièvre et de ses récits contradictoires. Yellow Jack ne procure pas seulement une rencontre intense de fiction avec une importante phase historique de la ville mais aussi une étude sophistiquée sur le rôle de la représentation visuelle pour la documentation de telles horreurs, dont la prose est profondément enracinée dans les odeurs et les bruits du temps et du lieu. Cet article traitera donc $d u$ profond engagement du roman avec les différentes "modalités sensuelles" d'un lieu particulier des États du Sud.

In ways comparable to the horrors of Hurricane Katrina and its aftermath in 2005, the series of yellow fever epidemics that devastated New Orleans through the nineteenth century were also the result, in part, of the city's geographical position, its unforgiving climate, and the policies of interested parties; the fever's awful death toll was likewise accompanied by a grotesque array of sights, sounds and smells. This article will focus upon Josh Russell's 1999 novel Yellow Jack, which provides a complex portrait of the mid-nineteenth-century city, its fever epidemics, and its conflicting narratives. As well as providing an intense fictional encounter with a formative period in New Orleans's history, Yellow Jack is a sophisticated study of the role of visual imagery in documenting such horrors, whose prose is steeped in the smells and sounds of the time and place. This article, then, will discuss this novel's intense engagement with the various "senses" of a very particular Southern place. 
INDEX

Keywords : Josh Russell, Yellow Jack, New Orleans, yellow fever, photography, senses

Mots-clés : Josh Russell, Yellow Jack, La Nouvelle-Orléans, fièvre jaune, photographie, les sens

\section{AUTEUR}

OWEN ROBINSON

University of Essex 